\title{
Участие на родителите в процеса на слухово-речевата рехабилитация при тежко чуващи деца
}

\author{
Ф. Михайлова, П. Руев \\ Шумен
}

\begin{abstract}
Резюме
Усвояването на езика е процес, който протича през целия живот - започва от първите месеци и продължава през годините на зрялост. Детето с вродена значителна загуба на слуха, няма натрупан речеви опит, върху който да се опира при по-нататъшното развитие, или в случай, че увреждането е придобито до тригодишна възраст, този опит бързо губи своето значение. Основното и най-важно е работата с него да започне възможно най-рано след поставянето на диагнозата и слуховия апарат. Необходим е избор на адекватна стратегия за рехабилитация, насочена към използването на най-сензитивните периоди в развитието и предпазване от появата на отклонения. Условия, осигуряващи богата речева практика в семейството, също имат важно значение за развитието на речта на децата с нарушен слух.

Първостепенната задача на специалистите е да разкрият пред родителите огромното значение на семейната среда за развитието на детето с увреден слух, както и пълноценното им участие в общуването с него и цялостния процес на слухово-речева рехабилитация. Езикът за детето с увреден слух придобива „смисъл“, единствено в междуличностните отношения с родителите и другите заобикалящи го лица.

В този смисъл, участието на семейството е един от най-съществените фактори за развитие и възпитание на детето с увреден слух, които са били пренебрегвани до скоро.
\end{abstract}

$\mathrm{P}$ анното диагностициране на слуховото нарушение и възможно най-ранното въздействие върху детето с увреден слух и неговото семейство, съ3дават благоприятни условия за преодоляване на негативните последици от органичното увреждане. Дълго време е било прието, терапевтичната работа да не започва до 3 - 4-годишна възраст. Но съвременните изследвания показват, че ако до този възрастов етап на детето с увреден слух не се осигури адекватно звукоусилване и ефективна езикова стимулация, то значително изостава по отношение на лингвистичното си развитие (Н. Балканска, 1998).

От диагностична гледна точка за нарушения в речевото развитие на детето може да се говори тогава, когато даден етап закъснява с повече от 6 месеца по отношение на общоприетите норми за речево развитие.

Проведени наблюдения убедително доказват, че съществените различия между глухите и чуващите деца се проявяват още през първата година и рязко нарастват в ранното детство. Една от най-съществените разлики е бързото и интензивно овладяване на речта, което при глухото дете не се проявява. Чуващите деца към третата година до голяма степен усвояват фонетиката, морфологията и граматическата страна на езика. Широко и правилно използват речта в нейните различни функции. Появява се силна мотивация за речево общуване. Поради тези причини различията между чуващи и глухи деца в края на ранното детство са много големи и се задълбочават още повече, ако на детето със слухо- 
ви нарушения не се предостави възможност за овладяване на мануален или словесен език (А. Балтаджиева, Сл. Лозанова, 2001).

За методите и средствата за обучение на деца със слухови нарушения може да кажем и напишем много, но въпросът за ефективността им си остава открит. Разглеждайки постиженията в областта на произносителната страна на устната реч, в не малко случаи качеството на произношение на децата си остава незадоволително.

При овладяването и развитието на речта при деца със слухово нарушение влияние оказват редица фактори, които се намират в тясна зависимост помежду си. Отделните автори изтькват различен брой, но независимо как ги дефинират, ясно се откроява повторението, респективно и значението на няколко от тях:

- степен и тип на слуховото увреждане;

- време на настьпване на увреждането;

- социална среда;

- ранна диагностика;

- използване на сензитивният период за слухова перцепция и овладяване на речеви умения;

- психологически и емоционално-волеви особености на детето;

- участие на семейството;

- компетентност на екипа работещ с детето ѝ

- наличие и използване на аудио и визуални средства (В. Кацарска, 2006).

Както вече казахме, участието на семейството е един от съществените фактори за развитие и възпитание на детето с увреден слух.

Bсе повече съвременни изследвания в областта на слухово-речева рехабилитация акцентират върху умението за комуникация, а не конкретно върху овладяването на езика (който сам по себе си е неин компонент) и умението за правилно произношение. Wells (1981) представя редица доказателства, за особената роля на обществото и социалната среда. Най-големият проблем при децата със слухови нарушения се оказва умението за общуване.

За развитието на детския говор извънредно значение имат междуличностните му отношения с родителите и другите заобикалящи го лица. В тези взаимоотношения езикът придобива „смисъл“ за децата. Личностните характерис- тики, възрастта, пола, социалното положение на хората заобикалящи детето, привързаностите, особено ранните или отблъскванията им бързо и трайно се заучават чрез т. нар. „механизъм на запечатване“ (imprinting). Ако междуличностната мотивация на детето е несъответна или не намира адекватен човешки отговор, не се развиват нито езиковите функции, нито интелигентността.

Откриването на слухово нарушение, поне в началото шокира родителите и прекъсва за известен период нормалната комуникация „дете- родител“. Точно в този момент възниква и големият проблем относно по нататъшното общуване в семейството и се заражда така наречената комуникативна криза. Ограниченото и недостатъчно общуване може да доведе до по-честа заболеваемост, социална изолация и отчужденост у детето.

За да се избегнат или намалят до минимум негативните последици при поставянето на първоначалната диагноза е важно да се знае, че първата консултация започва от момента на срещата между лекарят, родителите и детето. Това е стресиращо събитие за родителите и подходът на лекаря в този момент може да окаже влияние върху цялото семейство за години напред. Обикновено е минал известен период докато се вземе окончателно решение да се посети лекарски кабинет и да се направи изследване на слуха на детето. Проявявали са съпротиви срещу изразено съмнение от страна на близки, учители или приятели, че детето може би не чува. Ако самите родители са забелязали проблема, вероятно са правили нееднократни опити сами да установят дали детето им чува или не. При поставяне на диагноза от лекар, обикновено те разбират само, че детето им не е като другите. Първоначално, част от родителите не задават почти никакви въпроси, тъй като за да възприемат тази нова и шокираща за тях информация им е необходимо време. Други ни затрупват с въпроси, които до голяма степен нямат отношение към поставената диагноза. Именно в този момент предоставянето на достатъчно и в достъпен вид информация от страна на лекаря и в последствие от слуховоречевият рехабилитатор е съществен елемент от цялостния процес на работа с родителите. Умението да ги изслушваме, да разбираме 
техните емоции и да им вдъхнем увереност, че могат да се справят с вземането на всяко едно решение, е първата крачка в изграждането на отношения базирани на доверие, разбиране (без да бъдат съдени) и оказване на професионална подкрепа.

Психологически изследвания показват, че след осъзнаването на диагнозата родителите обикновено преминават през различни етапи - шок, отрицание, гняв, депресия, безразличие, реорганизация или приемане на глухотата и адаптация и активно включване във възпитанието, слухово-речевата рехабилитация на детето, неговото обучение и социализация. Някои от тези етапи се преминават от тях за няколко дни, други продължават с години. На базата на свое изследване Freeman at al. (1971 по М. Harvey, 1989) достига до извода, че времето между първото установяване на проблема от родителите и професионалното потвърждаване на слуховия дефицит е средно около година. Това до голяма степен зависи и от индивидуалните особености на отделните родителски личности. Адекватното приемане на проблема на детето може да бъде ускорено или забавено в зависимост от действията или бездействията на родителите, лекарите и слухово-речеви рехабилитатори. Една от най-важните задачи на специалистите е да разкрият огромното значение на семейната среда за развитието на детето с увреден слух, както и да подчертаят необходимостта от пълноценното им участие в общуването с него. Трябва да сме сигурни, че говорим на разбираем за семейството език, не използваме професионални термини и незабравяме, че с последиците от взетите решения ще живеят те, а не ние.

Не е възможно да се обхванат и опишат всички възможни реакции на хора поставени в аналогични ситуации и обстоятелства, няма и универсални методи и подходи за взаимодействие и преодоляване на негативните емоции. Задълбоченото проучване, наблюдението и изучаването на всички емоционални реакции на родителите на деца със слухови нарушения, биха помогнали на специалистите да изградят по-продуктивни стратегии за взаимодействие. В нашата съвместна практика се стремим да изградим такава работеща стратегия за работа с родители на деца с увреден слух.
След установяване на степента на нарушение на слуха следващата по значимост стъпка е ранното слухопротезиране. Изборът на личен слухов апарат се прави съвместно с лекаря в зависимост от намалението на слуха, финансовите средства на семейството, избраната фирма и пр.. Родителите от своя страна правят своя избор, но тяхната задача е много по-съществена в процеса на адаптиране на детето към слуховия апарат и постоянното му използване. В този момент слухово-речевият рехабилитатор следва да мотивира както детето, така и родителите в реалната полза от всекидневното носене на слухов апарат и последващата слухово-речева рехабилитация. Полезно за мотивирането на семейството е да си води дневник, в който да се записва как детето реагира след слухопротезирането, как протича адаптирането към апарата и всичко което по някакъв начин прави впечатление. По този начин се получава и обратна връзка към лекаря, който прави настройките на апаратите и рехабилитатора относно изпълнението на поставените от него задачи.

Независимо от степента на нарушение на слуха езиковото развитие протича със специфики и това изисква задължителна слухово-речева рехабилитация. На практика тя трябва да започне непосредствено след диагностициране на настьпилото нарушение.

В голям процент от случаите първоначалните очаквания на родителите са единствено в посока научаване на словесния (вербалния) език, от детето,а не толкова умението за комуникация. Човек се ражда с потребност от общуване. В това отношение и децата с увреден слух загуба не правят изключение. Неудовлетворяването на тази човешката потребност от общуване се отразява изключително негативно върху цялостното развитие (В. Кацарска, 2006). От огромно значение е всички опити на детето за комуникация да се поощряват.

Ролята на слухово-речевият рехабилитатор е да подпомогне родителите при разбирането на комуникативното съдържание, изразявано от детето и даване на адекватен, ответен отговор с вербални и невербални средства. На този етап родителите са в най-добра позиция да бъдат първите терапевти на детето. 
Вкъщи те и тяхното дете с увреден слух се намират в естествената си среда, в която ежедневните ситуации (времето за хранене, преобличане, лягане и т. н.) са идеални условия за акустична и езикова стимулация. При работата с родителите слухово-речевият рехабилитатор използва различни методи. Например чрез демонстрацията в домашни условия или кабинет за рехабилитация на слуха и говора, родителите наблюдават специалиста, който демонстрира упражнения насочени към стимулации на слуховото възприятие и езиковото развитие на детето. След това, провеждат аналогични упражнения в дома си. На база дългогодишна практика, може да се направи заключението, че в зависимост от възрастта на детето родителите е добре да присъстват на всички занятия, когато то е под 2 годишна възраст и на 2 до 4 занятия при деца над 3 години.

Специалистьт дискутира възникнали в процеса на работа въпроси, чувствата които изпитват, докато работят с детето си, къде и кога имат възможност да се занимават с него през седмицата и т. н. Рехабилитаторът поставя конкретни задачи пред тях за времето до следващото посещение. В съвместната дейност родителите също така, трябва да се ръководят от принципа, че на детето е необходимо да се дават задачи, които съответстват на развитието му и да бъдат логическо продължение на наученото до момента. Всяко избързване, не следване на последователността от упражнения, както и хаотичната, нецеленасочена работа, води до забавяне на рехабилитационния процес, а понякога и до отказ от самото дете да говори.

Основно условие е детето да не бъде просто пасивен реципиент на лингвистичните въздействия, а активно да участва в процеса на комуникация.

Работата с деца изисква доброжелателност, интерес и проява на готовност за разбиране. Това е въпрос както на познание на отделните периоди на възрастово развитие, така и на умение за емоционална адаптация.

Всяко семейство е строго индивидуално и има различни нужди, които се променят с течение на времето. Ние трябва да сме в състояние да приемаме разликите в семейните структури, културата, религиозните възгледи, образованието и всички други фактори, които засягат ежедневния живот и респективно работата ни с децата. Постоянната обратна връзка и комуникация между слухово-речевият рехабилитатор и лекар УНГ е от съществено значене. Например при проблем в настройките на личния слухов апарат или кохлеарния имплант още след първата - втората среща с детето, рехабилитаторът би могъл да установи разликата в говора и респективно да информира за това лекаря. Той от своя страна веднага да отстрани проблема. Родителите трябва добре да разберат значението на своето участие в този екип, както и продължителността на процеса. Слухово-речевата рехабилитация се провежда няколко пъти седмично, а посещението в лекарски кабинет веднъж месечно (може и по-рядко), а през цялото останало време семейството е движещото звено в обучението, възпитанието и цялостното развитие на детето с увреден слух.

Следващ етап е обсъждането на възможностите и необходимостта от поставяне на кохлеарен имплант, ефекта който ще има за детето, последващите стъпки и всички въпроси които възникват пред родителите се дискутират с лекаря и слухово-речевият рехабилитатор. Всеки специалист според компетентността си излага пред родителите различни алтернативни варианти на решение на отделните казуси, възможните проблеми и стъпките за разрешаването им.

Информираме семейството и за възможностите за образование които предлага даденото населено място, социалните услуги, ползване на ресурсно подпомагане, финансова подкрепа от страна на държавата, норматив и всичко друго което е от нашите компетенции.

Във всеки един етап от обсъжданията, вземането на решения, планиране на дейностите и провеждане на слухово-речева рехабилитация, трябва да са привлечени двамата родители, а повъзможност и разширеното семейство.

Забавянето по различни причини, включително и недоцценяване на проблема от тяхна страна, може да доведе до трайни последствия както за езиковото, така и емоционалното и интелектуално развитие на детето.

Трябва да се признае че проблема за речевото развитие на децата със слухови нарушения, независимо от постигнатите успехи в теоретичен и практически план, не може да се приема за решен.

Както вече посочихме в, речта при всяко дете се формира индивидуално, но развитието е възмож- 
но само в условия на активно общуване. Всяко дете се ражда с вродена способност да говори, но кога и как ще се научи да го прави зависи от родителите, средата и възможно най-ранна интервенция и слухово-речева рехабилитация. За съжаление функциониращата у нас система обхваща децата с увреден слух след диагностициране, а понякога и по-късно, като по този начин се изключва въздействието на един от най-важните възрастови периоди - първите месеци и години от живота на детето, което води до допълнително забавяне темпа на развитие.
Съществен пропуск все още си остава е недостатъчната разгърнатост на системата за ранна интервенция в страната, което прави невъзможно оказването на терапевтична помощ на всяко нуждаещо се семейство. Допълнителна бариера представлява и фактът, че липсва приемственост между медицинските звена (поликлиники, аудиологични кабинети и т. н.) и терапевтичната система по отношение популяризирането на програмите за работа с децата с увреден слух в ранните етапи от живота им (H. Баканска, 1998). 